\title{
Diallel analysis to choose parents for black bean (Phaseolus vulgaris L.) breeding
}

\author{
L.M. Moura ${ }^{1}$, P.C.S. Carneiro ${ }^{1}$, N.M. Vale ${ }^{2}$, L.D. Barili ${ }^{2}$, L.C. Silva ${ }^{2}$, \\ J.E.S. Carneiro ${ }^{2}$ and C.D. Cruz ${ }^{1}$ \\ ${ }^{1}$ Departamento de Biologia Geral, Universidade Federal de Viçosa, Viçosa, \\ Brasil \\ ${ }^{2}$ Departamento de Fitotecnia, Universidade Federal de Viçosa, Viçosa, MG, \\ Brasil \\ Corresponding author: L.M. Moura \\ E-mail: lisandrammoura@yahoo.com.br
}

Genet. Mol. Res. 15 (3): gmr.15038574

Received February 19, 2016

Accepted April 11, 2016

Published August 29, 2016

DOI http://dx.doi.org/10.4238/gmr.15038574

Copyright $($ C) 2016 The Authors. This is an open-access article distributed under the terms of the Creative Commons Attribution ShareAlike (CC BY-SA) 4.0 License.

\begin{abstract}
In this study, conducted in two different seasons, we aimed to choose parents to obtain promising segregating populations for the extraction of black bean (Phaseolus vulgaris L.) lines that are superior in terms of disease resistance, plant architecture, and grain yield. Twelve parents were arranged in two groups to compose a partial diallel in a $5 \times 7$ scheme. Group 1 was composed of parents with black grains and erect plant architecture, while group 2 was composed of parents that had carioca grains and were resistant to the main fungal diseases that occur in the common bean. The following traits were evaluated: severity of angular leaf spot (ALS), plant architecture (PAG), and grain yield (YIELD). The data were analyzed according to a partial diallel model using parents and $\mathrm{F}_{1}$ hybrids. In the genetic control of ALS and PAG, additive effects were predominant, while for YIELD, additive effects were predominant in one season and dominance effects were in
\end{abstract}


another season, because it is a more complex trait than ALS and PAG. For YIELD, we observed an interaction between general combining ability and specific combining ability between seasons. The genes that control ALS, PAG, and YIELD were in eight of the 12 parents evaluated in the diallel. The cultivar 'BRS Estilo' is suitable to use as a parent in common bean breeding in terms of ALS, PAG and YIELD. Recurrent selection is the most recommended option for simultaneously breeding for PAG, YIELD, and resistance to angular leaf spot in bean culture.

Key words: Phaseolus vulgaris L.; Diallel analysis; Plant architecture; Grain yield

\section{INTRODUCTION}

The common bean (Phaseolus vulgaris L.) is the most important legume for human consumption in several nations of Latin America, Africa, and Asia (Hnatuszko-Konka et al., 2014). It is an excellent source of protein, carbohydrates, and minerals such as iron and zinc, in addition to other nutrients (Gepts et al., 2008). Brazil is one of the greatest producers and consumers of beans in the world (Food and Agriculture Organization of the United Nations, http://faostat3.fao.org/browse/Q/QC/E). Aside from carioca beans, other types of bean are grown in the country, such as black beans, particularly in the states of Rio Grande do Sul, Santa Catarina, Paraná, Rio de Janeiro, and Espírito Santo (Costa et al., 2011). Although it is the second most consumed bean in Brazil, national black bean production has been insufficient to supply the domestic market, which annually imports more than 100 million tonnes (Pereira et al., 2013).

The search for new cultivars is routine in breeding programs for this legume, mainly because those currently grown still lack one or more features of some traits simultaneously, such as grain yield, commercial appearance of the grains, plant architecture, and disease resistance. Plants with an erect architecture suffer fewer losses during mechanical harvesting; this facilitates crop management, provides a better quality of grains harvested, and results in a lower incidence of pathogens (Pires et al., 2014).

Bean diseases are the principal causes of low yield (Coyne et al., 2003), particularly those caused by fungi such as anthracnose, white mold, angular leaf spot, rust, and fusarium wilt. The use of resistant cultivars is one of the most efficient strategies to control these diseases (Miklas et al., 2006).

Emphasis has been placed on breeding beans through hybridization, the success of which depends on the efficiency of the parents chosen. Crosses between parents should generate segregating populations with high variability and a suitable average for the selection of superior lines in relation to the traits of interest (Fehr, 1987). In the efficient choice of parents, diallel crosses are particularly important, as they provide information about the type of predominate gene action and stem from estimates of the general and specific capacity of combination of the parents, which helps the breeder in choosing the most suitable selection strategy.

One limitation of diallel crossings is the large number of crosses necessary in order to evaluate a certain number of parents. Partial diallels consist of crossing two distinct groups of parents, and are mainly used when there is no interest in evaluating crosses arising from parents of the same group (Miranda Filho and Geraldi, 1984). This allows one to maximize the crosses between parents that are complementary in terms of desirable phenotypes. Essentially, partial

Genetics and Molecular Research 15 (3): gmr.15038574 
diallels correspond to Comstock and Robinson's (1952) Design II, in which the effects of the parents are fixed, and the study of Miranda Filho and Geraldi (1984) and Geraldi and Miranda Filho (1988), who adapted the diallelic models of Gardner and Eberhart (1966) and Griffing (1956).

In Brazil, the common bean is cultivated more than one season per year in practically all of the states; therefore, it is subject to different environmental conditions and genotype $\mathrm{x}$ environment ( $\mathrm{G}$ x E) interactions (Torga et al., 2013). Obtaining superior lines that are adapted to various environments is one of the basic objectives of bean breeding. However, the breeder often only considers the effects of the $\mathrm{G} x \mathrm{E}$ interaction in the cultivar recommendation phase.

The $\mathrm{G} \times \mathrm{E}$ interaction is the differential expression of genes in relation to the environment in which the genotypes are evaluated, and it is possible to select genotypes that have little interaction with the environment. The G x E interaction should be considered in the initial phases of breeding programs, in which the evaluation of the diallel is conducted in different environmental conditions for a more accurate choice of parents. This early evaluation is particularly relevant when it refers to quantitative traits that, generally speaking, are governed by many genes and have great environmental influence, such as grain yield and plant architecture (Kelly and Adams, 1987).

In summary, there is a continual search for superior cultivars and a lack of studies that evaluate the $\mathrm{G} x \mathrm{E}$ interaction during the initial phases of bean breeding programs. Therefore, in this study that was conducted in two distinct seasons, we aimed to select parents in order to obtain promising segregating populations for extracting superior black bean lines in terms of plant architecture, disease resistance, and grain yield.

\section{MATERIAL AND METHODS}

Five black bean parents and seven carioca bean parents were used, all of which differed in terms of architecture (PAG), severity of angular leaf spot (ALS), and grain yield (YIELD) (Table 1). These parents were crossed in a partial diallel scheme. The five black bean parents ('L 20', 'Xamego', 'TB 94-01', 'BRS Valente', and 'Diamante Negro') made up group 1, while the seven carioca bean parents ('RP 1', 'BRS Estilo', 'VC 12', 'VC 20', 'CNFC 10720 ', 'MAI 1813', and 'VC 16') made up group 2.

Table 1. Description of the parents used in the diallelic crosses.

\begin{tabular}{|c|c|c|c|c|}
\hline Parent $^{1}$ & Origin & Type of grain & Plant architecture & Resistance \\
\hline L 20 & UFV $^{2}$ & Black & Semi-erect & Rust/Anthracnose \\
\hline Xamego & Agreement $^{3}$ & Black & Erect & Fusarium wilt \\
\hline TB 94-01 & EMBRAPA & Black & Erect & No information \\
\hline BRS Valente & EMBRAPA & Black & Erect & Anthracnose \\
\hline Diamante Negro & Agreement & Black & Semi-erect & Blight \\
\hline RP 1 & UFLA $^{4}$ & Carioca & Erect & Fusarium wilt \\
\hline BRS Estilo & EMBRAPA & Carioca & Erect & Rust \\
\hline VC 12 & UFV & Carioca & No information & Rust \\
\hline VC 20 & UFV & Carioca & Semi-erect & Rust \\
\hline CNFC 10720 & EMBRAPA & Carioca & Erect & White mold \\
\hline MAI 1813 & UFLA & Carioca & No information & Angular leaf spot \\
\hline VC 16 & UFV & Carioca & Semi-erect & Angular leaf spot \\
\hline
\end{tabular}

${ }^{1}$ The first five parents constituted group 1 and the remainder, group 2 in the diallelic crosses. ${ }^{2}$ Universidade Federal de Viçosa. ${ }^{3}$ Agreement between Empresa Brasileira de Pesquisa Agropecuária)/EMGOPA (Empresa Goiana de Pesquisa Agropecuária). ${ }^{4}$ Universidade Federal de Lavras.

Genetics and Molecular Research 15 (3): gmr.15038574 
The crosses were conducted in a greenhouse at the Department of Plant Science of Universidade Federal de Viçosa (UFV) without emasculation of the floral bud, as described by Peternelli et al. (2009). The $F_{1}$ seeds obtained were sown in a field together with the parents, totaling 47 treatments ( 35 hybrids +12 parents), in the winter of 2012 and dry season of 2013, in a randomized block design with three replications. The plots were composed of three $1-\mathrm{m}$ lines, with a plant density of 15 seeds per meter and $0.50 \mathrm{~m}$ between each line.

The experiments were conducted at the Coimbra Experimental Station in Coimbra, MG, Brazil, which belongs to the Department of Plant Science of UFV (690 m above mean sea level, $20^{\circ} 45^{\prime} \mathrm{S}$ and $\left.42^{\circ} 51^{\prime} \mathrm{W}\right)$. The crop treatments adopted were recommended for bean cultivation in the region.

The evaluation of PAG and ALS was conducted in the winter of 2012 and the dry season of 2013. PAG was evaluated close to harvest using the grading scale proposed by Ramalho et al. (1998a). This scale ranges from 1 to 5 in the following manner: 1, erect plant with a stem and a few branches; 2 , erect plant with some branches and a short guide; 3 , semiprostrate plant with branches and a medium guide; 4 , prostrate plant with branches and a long guide; 5 , completely prostrate plant with many branches and very long guides.

ALS was evaluated based on the natural occurrence of the disease in the field, using a grading scale modified by Inglis et al. (1988). This scale ranges from 1 to 9 in the following manner: 1, plants without any symptoms of disease; 3 , presence of lesions on 5 to $10 \%$ of the foliar area, without sporulation of the pathogen; 5, presence of lesions on more than $20 \%$ of the foliar area and presence of several sporulated lesions; 7, presence of lesions on more than $60 \%$ of the foliar area with symptoms of chlorosis and necrosis; 9 , lesions on $90 \%$ of the foliar area, frequently associated with defoliation and plant death. After harvest, the plants were threshed, weighed, and YIELD was measured in $\mathrm{kg} / \mathrm{ha}$.

\section{Statistical analyses}

The data were subjected to analysis of variance and the averages of YIELD, PAG, and ALS of the parents and of the $F_{1}$ hybrids were analyzed using the Griffing model (1956) adapted for partial diallels by Geraldi and Miranda Filho (1988), according to the following model:

$$
\left.Y_{i j}=\mu+1 / 2\left(d_{1}+d_{2}\right)+g_{i}+g_{j}^{\prime}+s_{i j}+e_{i j} \quad \text { (Equation } 1\right)
$$

where $Y_{i j}$ is the average of the cross that included the $i^{\text {th }}$ parent of group 1 and the $j^{\text {th }}$ parent of group $2 ; \mu$ is the general average of the diallel; $d_{1}$ and $d_{2}$ are the contrasts that include the averages of groups 1 and 2 and the general average; $g_{i}$ is the effect of the general combining ability (GCA) of the $i^{\text {th }}$ parent of group $1 ; g_{j}^{\prime}$ is the effect of the GCA of the $j^{\text {th }}$ parent of group $2 ; s_{i j}$ is the effect of the specific combining ability (SCA); and $e_{i j}$ is the average experimental error. The effect of genotype was considered as fixed and the effect of season was considered as random. The Genes program (Cruz, 2013) was used for all of the statistical analyses.

\section{RESULTS AND DISCUSSION}

YIELD and PAG were evaluated in the winter of 2012 and the dry season of 2013. Evaluation of ALS was only conducted in the winter of 2012 because of the natural occurrence 
of this disease in the field. The coefficients of experimental variation for all three traits were below 20\% (Table 2), indicating good experimental precision, and are in accordance with the values reported for experiments of this nature on bean cultures (Menezes Júnior et al., 2013; Oliveira et al., 2015). In the diallelic analysis, sources of treatment variation included the effects of the GCA of groups 1 and $2\left(\mathrm{GCA}_{1}\right.$ and $\left.\mathrm{GCA}_{2}\right)$, the SCA, and the contrast between the averages of the two parental groups $\left(\mathrm{G}_{1} v s \mathrm{G}_{2}\right)$ (Table 2).

Table 2. Summary of a diallelic analysis of severity of angular leaf spot (ALS) in the winter of 2012 (WIN 12) and plant architecture (PAG) and grain yield (YIELD) in the winter of 2012 (WIN 12) and dry season of 2013 (DRY 13).

\begin{tabular}{l|c|c|c|c|c|c}
\hline \multirow{2}{*}{ Source of variation } & d.f. & ALS MS & \multicolumn{2}{|c|}{ PAG MS } & \multicolumn{2}{c}{ YIELD MS } \\
\cline { 3 - 7 } & & WIN 12 & WIN 12 & DRY 13 & WIN 12 & DRY 13 \\
\hline Treatment & 46 & $3.60^{* *}$ & $0.35^{* *}$ & $0.55^{* *}$ & $1,766,102.89^{* *}$ & $1,086,142.24^{* *}$ \\
\hline $\mathrm{GCA}_{1}$ & 4 & $3.21^{* *}$ & $2.52^{* *}$ & $2.88^{* *}$ & $342,663.06^{\mathrm{ns}}$ & $1,403,614.09^{* *}$ \\
\hline $\mathrm{GCA}_{2}$ & 6 & 14.90 & $0.14^{\mathrm{ns}}$ & $0.99^{* *}$ & $7,888,078.54^{* *}$ & $781,542.18^{* *}$ \\
\hline $\mathrm{SCA}$ & 35 & $1.20^{* *}$ & $0.15^{\mathrm{ns}}$ & $0.21^{\mathrm{ns}}$ & $903,997.48^{* *}$ & $1,120,061.72^{* *}$ \\
\hline $\mathrm{G}_{1} v s \mathrm{G}_{2}$ & 1 & $21.57^{* *}$ & $0.01^{\mathrm{ns}}$ & $0.75^{*}$ & $901,697.51^{*}$ & $456,673.42^{\mathrm{ns}}$ \\
\hline Residual & 92 & 0.40 & 0.15 & 0.19 & $217,811.38$ & $304,214.34$ \\
\hline Average $\mathrm{G}_{1}$ & & 7.06 & 2.59 & 2.00 & 2,130 & 3,722 \\
\hline Average $\mathrm{G}_{2}$ & & 5.47 & 2.69 & 2.35 & 2,639 & 3,764 \\
\hline CV $(\%)$ & 10.32 & 13.78 & 18.16 & \multicolumn{2}{c}{15.74} & 12.14 \\
\hline
\end{tabular}

***Significant at the 1 and $5 \%$ levels of probability, respectively, according to a Student $t$-test; ns = not significant; d.f. $=$ degrees of freedom; $\mathrm{MS}=$ mean square; $\mathrm{CV}=$ coefficient of variation.

\section{Estimates of GCA and SCA in relation to ALS}

The contrast of $G_{1}$ versus $G_{2}$ was significant (Table 2), indicating that the two groups of parents differed in regards to resistance to angular leaf spot. Group 2 was superior, as it had a lower average score for the severity of the disease. The GCA of the parents of both groups, and the SCA of the hybrids, also had a significant effect in relation to ALS, indicating a difference in the concentration of favorable alleles between the parents of the same group and genetic divergence between the parents from different groups. There was a predominance of additive effects in the genetic control of resistance to angular leaf spot, as demonstrated by the greater value for the sum of squares of the GCA $\left(\mathrm{GCA}_{1}+\mathrm{GCA}_{2}\right)$ than that for the sum of squares of the SCA. Borel et al. (2011) also reported a predominance of additive effects in the genetic control of resistance to angular leaf spot when evaluating the natural occurrence of the disease in the field.

Considering the averages of the parents and hybrids (Table 3), we observed positive and negative dominance deviations, indicating that recessive and dominant genes, respectively, are involved in the genetic control of resistance to angular leaf spot. Considering the crosses involving the parent 'BRS Estilo', which had a severity score of less than 3 (resistant parent), the hybrids 'L 20'/“BRS Estilo', 'Xamego'/“BRS Estilo', and 'TB 94-01'/“BRS Estilo' exhibited positive deviations, whereas the hybrids 'BRS Valente'/'BRS Estilo' and 'Diamante Negro'/'BRS Estilo' exhibited negative deviations. The occurrence of dominant and recessive genes involved in the genetic control of a trait complicates its breeding. In this situation, one strategy would be to advance the generations in a way that determines the alleles, be they dominant or recessive, in order to make the selection effective.

The results of some previous studies indicate that the genetic control of resistance to angular leaf spot is monogenic or oligogenic (Caixeta et al., 2003; Mahuku et al., 2004). In these studies, the study of inheritance was based on only one parental cross. However, it should be

Genetics and Molecular Research 15 (3): gmr.15038574 
noted that the occurrence of different breeds of angular leaf spot has been reported in the literature (Sartorato, 2002; Sartorato and Alzate-Marin, 2004). Amaro et al. (2007) reported a gradation in symptoms among lines considered susceptible to angular leaf spot, and suggested that part of this gradation can be attributed to environmental effects and the polygenic control of the trait, because resistance to angular leaf spot has a complex inheritance. Borel et al. (2011) also reported that the inheritance of resistance to angular leaf spot is complex in some situations, with low-effect genes and environmental effects acting together with large-effect genes or modifying genes.

Table 3. Estimates of $\mathrm{GCA}_{1}, \mathrm{GCA}_{2}$, and SCA and average scores for the severity of angular leaf spot (in parentheses) in the winter of 2012.

\begin{tabular}{l|c|c|c|c|c|c|c|c}
\hline \multirow{2}{*}{ Parent } & \multicolumn{7}{|c|}{ SCA } & \multicolumn{2}{c}{ GCA 1} \\
\cline { 2 - 9 } & RP 1 & BRS Estilo & VC 12 & VC 20 & CNFC 10720 & MAI 1813 & VC 16 & \\
\hline L 20 & $-0.39(7.0)$ & 0.65 & $-0.09(7.3)$ & 0.05 & 0.68 & $-0.06(7.0)$ & $-0.24(6.7)$ & 0.52 \\
\hline Xamego & $0.06(6.7)$ & 1.43 & $0.36(7.0)$ & $-1.49^{* *}(4.0)$ & 0.14 & $-0.27(6.0)$ & $-1.45^{* *}$ & $-0.27^{*}(7.0)$ \\
\hline TB 94-01 & $-1.15^{* *}$ & 0.22 & $-0.18(6.7)$ & 0.30 & 0.26 & $-0.15(6.3)$ & $0.01(6.3)$ & $-0.06(6.7)$ \\
\hline BRS Valente & $0.00(6.7)$ & $-0.96^{* *}(3.6)$ & $0.30(7.0)$ & -0.22 & 0.08 & $0.34(6.7)$ & $0.15(6.3)$ & $-0.21^{*}(6.7)$ \\
\hline Diamante Negro & $0.09(7.0)$ & $-1.20^{* *}(3.7)$ & $0.06(7.0)$ & 0.54 & 0.17 & $-0.90(5.7)$ & $0.58(7.0)$ & 0.03 \\
\hline GCA $_{2}$ & $0.71(7.0)$ & $-1.32^{* *}(2.7)$ & $0.75(6.7)$ & $-0.39^{* *}(5.0)$ & $-0.36^{* *}(4.0)$ & $0.38(6.7)$ & $0.23(6.3)$ & \\
\hline
\end{tabular}

***Significant at the 1 and $5 \%$ levels of probability, respectively, according to a Student $t$-test. Group 1: 'L 20', 'Xamego', 'TB 94-01', 'BRS Valente', and 'Diamante Negro'; group 2: 'RP 1', 'BRS Estilo', 'VC 12', 'VC 10720', 'MAI 1813', and 'VC 16'.

When breeding complex inheritance traits, some breeders have successfully used the recurrent selection strategy in bean breeding, such as in the cases of precocity (Silva et al., 2007), resistance to angular leaf spot (Amaro et al., 2007), PAG (Pires et al., 2014), and carioca-type YIELD (Ramalho et al., 2005). In the case of resistance to angular leaf spot, Amaro et al. (2007) obtained genetic progress of $6.4 \%$ per cycle in four cycles of recurrent phenotypic selection using this strategy. In autogamic plants, choosing populations with great potential maximizes the chances of success in breeding programs (Ramalho et al., 2001). Therefore, diallel GCA and SCA estimates facilitate the identification of potential parents for the breeding of complex inheritance traits in terms of favorable allele frequency and divergence between crossed parents.

Regarding estimates of the effects of GCA on ALS (Table 3), in group 1, the parents 'Xamego' and 'BRS Valente' were noteworthy, and in group 2, 'BRS Estilo', 'VC 20', and 'CNFC 10720' had the lowest significant estimates of GCA. Low scores indicate parents with high resistance to angular leaf spot. However, it is worth noting that although there was a significant effect of the GCA of group 1, the frequency of the alleles for resistance to angular leaf spot in these parents was low because of their high scores for disease severity (Table 3). These results can be explained by the fact that, in a partial diallel, these estimates are arrived at for each group, using the opposite group as testers, so that the GCA estimate of one parent is a function of the difference in allelic frequency between all of the parents in the opposite group. Therefore, of the parents evaluated, only 'BRS Estilo' from group 2 had a significant negative GCA that was associated with a severity score of less than 3 .

In terms of the SCA estimates, which in a diallel indicate the diversity of the crossed parents, the crosses 'BRS Valente'/'BRS Estilo' and 'Diamante Negro'/'BRS Estilo' stood out (Table 3) because of the greater frequency of favorable alleles that are involved in resistance to angular leaf spot. Therefore, the parents 'BRS Valente' and 'Diamante Negro', although susceptible (with severity scores higher than 6), possess genes that are complementary to angular leaf spot resistance genes that are present in the parent, 'BRS Estilo'.

Genetics and Molecular Research 15 (3): gmr.15038574 


\section{Estimates of GCA and SCA in regards to PAG}

The contrast between the two groups was only significant in the dry season of 2013 (Table 2), indicating that it was only in this season that the groups differed in terms of PAG. Group 1 was superior as it had lower average PAG scores, which is indicative of plants with erect architecture. It is worth mentioning that the scores of the parents were all lower than 3.3, indicating an elevated frequency of favorable alleles in the control of PAG among the parents involved in the diallel.

In the winter of 2012, only the GCA of the parents of group $1\left(\mathrm{GCA}_{1}\right)$ had a significant effect (Table 2), indicating that there was a difference in the concentration of favorable alleles only among the parents of this group. In the dry season of 2013, there was a difference in the frequency of favorable alleles among the parents within each of the two groups of the diallel, as the GCA of the parents of both groups had significant effects. The SCA estimates in both seasons were not significant, indicating low genetic divergence among the parents of the two groups.

The sum of squares of the GCA $\left(\mathrm{GCA}_{1}+\mathrm{GCA}_{2}\right)$ was higher than the sum of squares of the SCA, indicating that there was a predominance of additive effects in both seasons for this trait. These results were expected, because the effect of SCA was not significant in the two seasons. A predominance of additive effects for PAG was also reported by Silva et al. (2013) when evaluating 14 lines of different bean types (carioca, black, and mulatinho) and their hybrid combinations in a partial diallel.

The parents 'TB 94-01' and 'L 20' from group 1 and 'VC 16' and 'BRS Estilo' from group 2 had the lowest significant GCA estimates in the winter of 2012. The parent 'TB 94-01' was noteworthy in both of the seasons in terms of the frequency of favorable alleles for PAG (Table 4). Among these parents, only 'BRS Estilo' stood out for resistance to angular leaf spot (Table 3).

\begin{tabular}{|c|c|c|c|c|c|c|c|c|}
\hline \multirow[t]{3}{*}{ Parent } & \multicolumn{7}{|c|}{ GCA } & \multirow[t]{3}{*}{$\mathrm{GCA}_{1}$} \\
\hline & RP 1 & BRS Estilo & VC 12 & VC 20 & $\begin{array}{l}\text { CNFC } \\
10720 \\
\end{array}$ & MAI 1813 & VC 16 & \\
\hline & \multicolumn{7}{|c|}{ Winter 2012} & \\
\hline L 20 & $-0.22(2.5)$ & $-0.15(2.5)$ & $0.05(2.7)$ & $0.26(2.8)$ & $0.05(2.8)$ & $0.13(2.8)$ & $0.22(2.8)$ & $-0.14 *(2.3)$ \\
\hline Xamego & $0.02(2.8)$ & $-0.07(2.7)$ & $-0.04(2.7)$ & $0.002(2.7)$ & $0.13(3.0)$ & $0.20(3.0)$ & $0.46(3.1)$ & $-0.04(2.3)$ \\
\hline TB 94-01 & $0.17(2.8)$ & $-0.09(2.5)$ & $-0.22(2.3)$ & $0.32(2.8)$ & $-0.05(2.7)$ & $-0.14(2.5)$ & $0.12(2.7)$ & $-0.20 * *(2.3)$ \\
\hline BRS Valente & $0.08(2.8)$ & $0.15(2.8)$ & $-0.14(2.5)$ & $-0.27(2.3)$ & $-0.14(2.7)$ & $0.10(2.8)$ & $0.02(2.7)$ & $-0.11(2.7)$ \\
\hline Diamante Negro & $0.16(3.5)$ & $0.06(3.3)$ & $0.10(3.3)$ & $0.30(3.5)$ & $0.10(3.5)$ & $0.17(3.5)$ & $-0.07(3.1)$ & $0.48(3.3)$ \\
\hline \multirow[t]{2}{*}{$\mathrm{GCA}_{2}$} & $0.06(2.8)$ & $-0.02(2.8)$ & $-0.05(2.8)$ & $-0.09(2.3)$ & $0.11(3.0)$ & $0.04(2.7)$ & $-0.05(2.3)$ & \\
\hline & \multicolumn{7}{|c|}{ Dry season 2013} & $\mathrm{GCA}_{1}$ \\
\hline L 20 & $-0.05(2.3)$ & $0.11(2.3)$ & $0.31(2.7)$ & $0.39(2.7)$ & $-0.02(2.7)$ & $0.41(3.0)$ & $0.00(2.2)$ & $0.00(1.7)$ \\
\hline Xamego & $0.08(2.3)$ & $0.25(2.3)$ & $-0.38(1.8)$ & $0.52(2.7)$ & $-0.05(2.5)$ & $0.04(2.5)$ & $-0.20(1.8)$ & $-0.13^{*}(1.8)$ \\
\hline TB 94-01 & $0.20(2.3)$ & $-0.13(1.3)$ & $0.24(2.3)$ & $0.31(2.3)$ & $-0.09(2.3)$ & $-0.00(2.3)$ & $-0.07(1.8)$ & $-0.25 * *(1.6)$ \\
\hline BRS Valente & $0.06(2.3)$ & $-0.10(2.0)$ & $0.10(2.3)$ & $-0.16(2.0)$ & $0.10(2.7)$ & $0.03(2.5)$ & $0.29(2.3)$ & $-0.12(1.8)$ \\
\hline Diamante Negro & $0.11(3.0)$ & $0.28(3.0)$ & $-0.02(2.8)$ & $-0.11(2.7)$ & $0.31(3.5)$ & $-0.26(2.8)$ & $-0.17(2.5)$ & $0.50(3.2)$ \\
\hline $\mathrm{GCA}_{2}$ & $0.00(2.3)$ & $-0.16^{*}(2.0)$ & $-0.03(2.3)$ & $-0.10(1.8)$ & $0.30(3.0)$ & $0.21(2.8)$ & $-0.22 * *(2.2)$ & \\
\hline
\end{tabular}

*,**Significant at the 1 and 5\% levels of probability, respectively, according to a Student $t$-test.

The joint diallelic analysis revealed a non-significant effect of the genotype $\mathrm{x}$ season interaction (Table 5), indicating that there was no difference in the behavior of the genotypes in the different seasons in relation to PAG. Non-significant G x E interactions for PAG have also been reported by other authors in bean cultivation (Moreto et al., 2007; Oliveira et al., 2015). The interactions $\mathrm{GCA}_{1} \mathrm{x}$ season, $\mathrm{GCA}_{2} \mathrm{x}$ season, and SCA x season were also non-significant (Table 5).

Genetics and Molecular Research 15 (3): gmr.15038574 
Table 5. Summary of a joint diallelic analysis of plant architecture (PAG) and grain yield (YIELD).

\begin{tabular}{|c|c|c|c|}
\hline \multirow[t]{2}{*}{ Source of variation } & \multirow[t]{2}{*}{ d.f. } & \multicolumn{2}{|c|}{ Square Averages } \\
\hline & & PAG & YIELD \\
\hline Genotype & 46 & $0.75 * *$ & $2,011,780.00^{* * *}$ \\
\hline $\mathrm{GCA}_{1}$ & 4 & $5.28^{* *}$ & $837,993.71^{\text {ns }}$ \\
\hline $\mathrm{GCA}_{2}$ & 6 & $0.87^{\mathrm{ns}}$ & $5,321,093.64^{\mathrm{ns}}$ \\
\hline SCA & 35 & $0.22^{\mathrm{ns}}$ & $1,635,024.57^{* *}$ \\
\hline Season & 1 & $0.00^{\mathrm{ns}}$ & $79,279.15^{\text {ns }}$ \\
\hline Genotype $\mathrm{x}$ season & 46 & $0.15^{\text {ns }}$ & $840,465.11^{* *}$ \\
\hline $\mathrm{GCA}_{1} \times$ season & 4 & $0.13^{\mathrm{ns}}$ & $908,283.43 *$ \\
\hline $\mathrm{GCA}_{2} \times$ season & 6 & $0.26^{\mathrm{ns}}$ & $3,348,527.03 * *$ \\
\hline SCA x season & 35 & $0.13^{\text {ns }}$ & $389,034.62^{*}$ \\
\hline Combined residual & 184 & 0.17 & $261,012.81$ \\
\hline General average & & 2.60 & $3,739.32$ \\
\hline CV $(\%)$ & & 15.82 & 15.56 \\
\hline
\end{tabular}

***Significant at the 1 and $5 \%$ levels of probability, respectively, according to an F-test; ns, not significant; d.f., degrees of freedom. $\mathrm{CV}$, coefficient of variation.

According to Teixeira et al. (1999), the main problem in breeding for PAG is environmental influence, i.e., highly favorable conditions, such as high humidity, or unfavorable conditions, such as extreme dryness, can complicate the discrimination of genetically distinct genotypes and result in them exhibiting the same PAG pattern.

In our study, discrimination of the parents in terms of PAG was more effective in the dry season of 2013 than in the winter, because the GCA estimates of both of the groups and the contrast $\mathrm{G}_{1}$ vs $\mathrm{G}_{2}$ were significant in the dry season, indicating a difference between the groups of parents in the frequency of favorable alleles expressed in this environment. The non-significance of the GCA estimates, and of the contrast $\mathrm{G}_{1} v s \mathrm{G}_{2}$ corroborates the fact that winter is the best season in which to discriminate for PAG. It is worth mentioning that winter sowing occurred at the end of August 2012. Therefore, this season could have been subjected to greater moisture because of the rain that starts in this region in September, which contributes to greater vegetative development and consequently decreases the discrimination of the plants in terms of architecture (Teixeira et al., 1999).

\section{Estimates of GCA and SCA in terms of YIELD}

The contrast between the two groups was only significant in the winter of 2012 (Table 2 ), indicating that the groups only differed in terms of YIELD in this season. Group 2 was superior, as it had a higher average value for this trait. In the winter of 2012, significant effects of $\mathrm{GCA}_{2}$ and SCA were observed (Table 2). The sum of squares of GCA $\left(\mathrm{GCA}_{1}+\mathrm{GCA}_{2}\right)$ was greater than the sum of squares of SCA, indicating that there was a predominance of additive effects in this season on the genetic control of YIELD. In the dry season of 2013, significant effects for estimates of $\mathrm{GCA}_{1}, \mathrm{GCA}_{2}$, and SCA were observed. In this season, dominance effects predominated in the genetic control of YIELD. These results suggest that the genes involved in the genetic control of YIELD are expressed differently in different seasons. Some previous studies have reported the predominance of additive effects (Kurek et al., 2001; Mendes et al., 2009), while others have reported a greater importance of dominance effects (Silva et al., 2013; Vale et al., 2015) in the genetic control of bean yield.

Regarding the GCA estimates (Table 6), the parents 'BRS Estilo' and 'CNFC 10720' from group 2 were noteworthy, with significant GCA estimates in the winter of 2012. In the dry season of 2013, the parents 'Diamante Negro' of group 1 and 'VC 16' of group 2 stood out. These parents had a greater frequency of favorable alleles in the genetic control of YIELD.

Genetics and Molecular Research 15 (3): gmr.15038574 
Diallel analysis for Phaseolus vulgaris L.

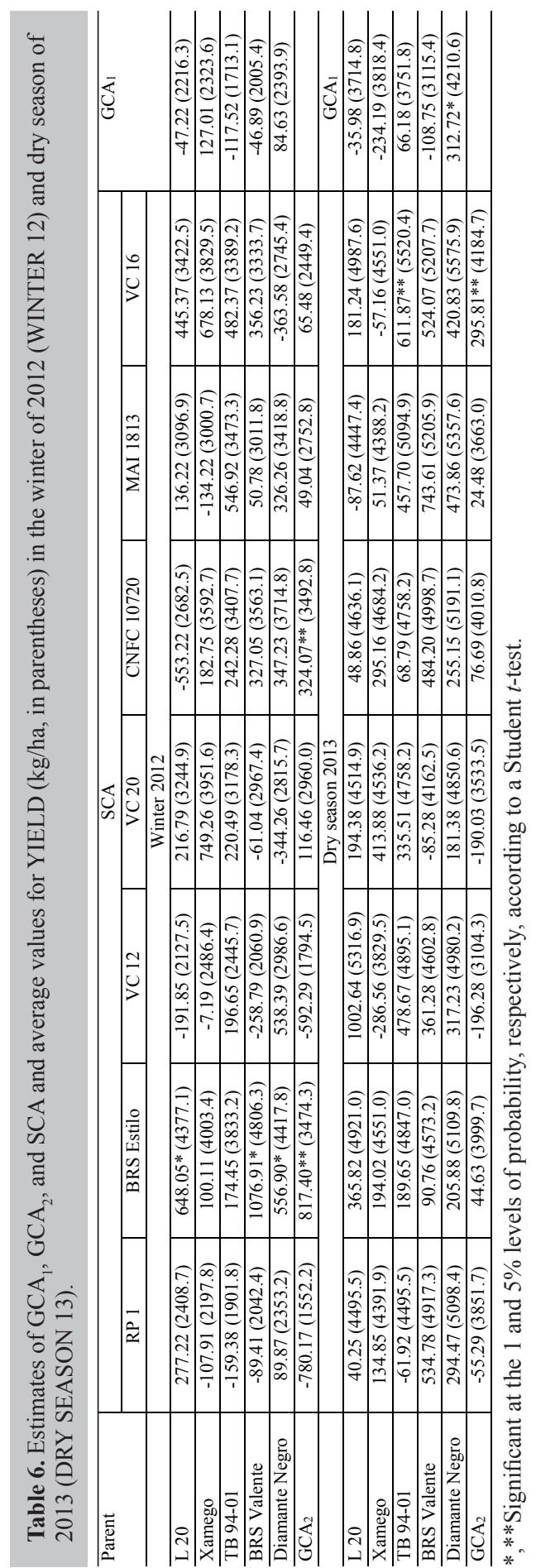

Genetics and Molecular Research 15 (3): gmr.15038574 
In regard to the hybrid combinations, in the winter of 2012, the crosses 'BRS Valente'/"BRS Estilo', 'L20'/'BRS Estilo', and 'Diamante Negro'/'BRS Estilo' were noteworthy because they had significant SCA estimates (Table 6), with at least one parent with a high GCA. In the dry season of 2013, the crosses that stood out were 'TB 94-01'/'VC 16' and 'BRS Valente'/'VC 16'. The SCA effect is useful in breeding, because its magnitude indicates the dimension of variability that can be exploited in each population, and there is a greater probability of obtaining transgressive segregants when the SCA effect is large. Some hybrid combinations, even though they did not have significant SCA estimates, are promising for extracting lines. For example, in the winter, all of the crosses that involved the parent 'BRS Estilo' had positive SCA estimates, and all of the hybrids surpassed the average of the parents by more than $800 \mathrm{~kg}$. The cross 'Diamante Negro'/'CNFC 10720' surpassed the average of the best parent ('CNFC 10720', $3492.8 \mathrm{~kg}$ ) by $222 \mathrm{~kg}$, and exhibited heterobeltiosis. In the dry season of 2013, the crosses 'BRS Valente'/'VC 16' and 'Diamante Negro'/'VC 16', which also had non-significant SCA estimates, surpassed the average of the best parent by 1022 and $1365 \mathrm{~kg}$, respectively.

In regards to ALS and YIELD, group 2 had lower average severity scores than group 1 in the winter, and consequently was statistically superior in terms of YIELD (Table 2), because the high ALS scores in group 1 reduced the YIELD of this group. In the dry season, there was no incidence of disease, as indicated by the non-significance of the contrast $\mathrm{G}_{1}$ vs $\mathrm{G}_{2}$ for YIELD. In the dry season, the parents 'BRS Estilo' and 'CNFC 10720' stood out in terms of the frequency of favorable alleles. These parents are also noteworthy in terms of ALS, because they had the lowest severity scores among the parents of the two groups. These results corroborate those of Amaro et al. (2007), who conducted recurrent phenotypic selection for resistance to angular leaf spot and obtained a genetic progress of $6.4 \%$ per cycle for resistance to angular leaf spot and $8.9 \%$ for YIELD.

The joint analysis indicated that there were significant effects of the genotype $\mathrm{x}$ season interaction on YIELD (Table 5). Seasonal effects were confounded by the effects of year, because the winter season was evaluated in 2012 and the dry season in 2013. Ramalho et al. (1998b) reported that the most important interactions for the common bean are genotype $\mathrm{x}$ season and genotype x year. Torga et al. (2013) concluded that it is more important to evaluate genotypes in different seasons and years rather than in different locations. Therefore, by evaluating the diallel in different seasons and/or years, the $\mathrm{G} x$ E interaction can be considered during the initial phase of breeding programs, which could result in obtaining lines with greater adaptability and behavioral stability. It is important to note that, owing to the difficulty of obtaining sufficient numbers of $F_{1}$ seeds, diallel evaluation in more than one environment and/or season with genotypes in the same generation, mainly the $\mathrm{F}_{1}$, is difficult.

The joint analysis also revealed significant effects of $\mathrm{GCA}_{1} \mathrm{x}$ season, $\mathrm{GCA}_{2} \mathrm{x}$ season, and SCA x season (Table 5). These results suggest that interactions between GCA, SCA, and season/year are highly complex. Therefore, one option for maximizing the potential of segregating populations (such as sources of lines) by increasing adaptability and behavioral stability would be to conduct multiple crosses among suitable parents in each season. However, the probability of success using this method is low, because of the large number of genes involved in the control of these traits (Carneiro et al., 2002). Furthermore, according to Ramalho et al. (2012), over the course of successful inbreeding in autogamous species, offspring isolation occurs, making it impossible to take advantage of the favorable alleles present in different individuals except by interbreeding among them. In this situation, one of the main options is the use of recurrent selection, in which favorable alleles are accumulated

Genetics and Molecular Research 15 (3): gmr.15038574 
in several stages. According to Menezes Júnior et al. (2013), the use of recurrent selection in bean culture also makes breeding programs more dynamic and organized.

Considering ALS, PAG, and YIELD, we found genes of interest in eight of the 12 parents involved in the diallel. This fact, combined with the interactions between GCA, SCA, and season/year for YIELD, indicates that the recurrent selection strategy is the most promising strategy for breeding these traits. Therefore, beginning with this study, UFV has begun a black bean breeding program using recurrent selection, in order to extract superior lines in terms of disease resistance, PAG, YIELD, and appearance simultaneously.

\section{Conflicts of interest}

The authors declare no conflict of interest.

\section{ACKNOWLEDGMENTS}

We thank Conselho Nacional de Desenvolvimento Científico e Tecnológico (CNPq), Coordenação de Aperfeiçoamento de Pessoal de Nível Superior (CAPES), and Fundação de Amparo à Pesquisa do Estado de Minas Gerais (FAPEMIG) in relation to the Common Bean Breeding Program of the Universidade Federal de Viçosa, Brazil.

\section{REFERENCES}

Amaro GB, Abreu AFB, Ramalho MAP and Silva FB (2007). Phenotypic recurrent selection in the common bean (Phaseolus vulgaris L) with carioca-type grains for resistance to the fungi Phaeoisariopsis griseola. Genet. Mol. Biol. 30: 584-588. http://dx.doi.org/10.1590/S1415-47572007000400014

Borel JC, Ramalho MAP, Abreu AFB and Maia LGS (2011). Genetic control of the angular leaf spot reaction in common bean leaves and pods. Sci. Agric. 68: 661-664. http://dx.doi.org/10.1590/S0103-90162011000600009

Caixeta ET, Borém A, Fagundes SA, Niestche S, et al. (2003). Inheritance of angular leaf spot resistance in common bean line BAT 332 and identification of RAPD markers linked to the resistance gene. Euphytica 134: 297-303. http:// dx.doi.org/10.1023/B:EUPH.0000004948.41083.1f

Carneiro JES, Ramalho MAP, Abreu AFB and Gonçalves FMA (2002). Breeding potential of single, double and multiple crosses in common bean. Crop Breed. Appl. Biotechnol. 22: 515-524. http://dx.doi.org/10.12702/1984-7033. v02n04a04

Comstock RE and Robinson HF (1952). Estimation of average dominance of genes. In: Heterosis (Gowen JW, ed.). Iowa State College Press, Ames, 494-516.

Costa JGC, Melo LC, Pereira HS, Del Peloso MJ, et al. (2011). BRS Esplendor common bean cultivar with black grain, upright growth and disease resistance. Crop Breed. Appl. Biotechnol. 11: 276-279. http://dx.doi.org/10.1590/S198470332011000300011

Coyne DP, Steadmanb JR, Godoy-Lutzc G, Gilbertsond R, et al. (2003). Contributions of the bean/cowpea CRSP to management of bean diseases. Field Crops Res. 82: 155-168. http://dx.doi.org/10.1016/S0378-4290(03)00035-2

Cruz CD (2013). Genes- software package for analysis in experimental statistics and quantitative genetics. Acta Sci. Agron. 35: 271-276. http://dx.doi.org/10.4025/actasciagron.v35i3.21251

Fehr WR (1987). Principles of line development. MacMillan, New York.

Gardner CO and Eberhart AS (1966). Analysis and interpretation of the variety cross diallel and related populations. Biometrics 22: 439-452. http://dx.doi.org/10.2307/2528181

Gepts P, Aragão FJL, Barros E, Blair MW, et al. (2008). Genomics of Phaseolus beans, a major source of dietary protein and micronutrients in the Tropics. In: Genomics of tropical crop plants (Moore PH and Ming R, eds.). Springer, New York, 113-143.

Geraldi IO and Miranda Filho JB (1988). Adapted models for the analysis of combining ability of varieties in partial diallel crosses. Braz. J. Genet. 11: 419-430.

Griffing B (1956). Concept of general and specific combining ability in relation to diallel crossing systems. Aust. J. Biol. Sci. 9: 463-493.

Genetics and Molecular Research 15 (3): gmr.15038574 
Hnatuszko-Konka K, Kowalczyk T, Gerszberg A, Wiktorek-Smagur A, et al. (2014). Phaseolus vulgaris - recalcitrant potential. Biotechnol. Adv. 32: 1205-1215. http://dx.doi.org/10.1016/j.biotechadv.2014.06.001

Inglis DA, Hagedorn DJ and Rand RE (1988). Use of dry inoculum to evaluate beans for resistance to anthracnose and angular leaf spot. Plant Dis. 72: 771-774. http://dx.doi.org/10.1094/PD-72-0771

Kelly JD and Adams MW (1987). Phenotypic recurrent selection in ideotype breeding of plant beans. Euphytica 36: 69-80. http://dx.doi.org/10.1007/BF00730649

Kurek AJ, Carvalho FIF, Assmann IC and Cruz PJ (2001). Capacidade combinatória como critério de eficiência na seleção de genitores em feijoeiro. Pesquisa Agropecu. Bras. 36: 645-651. http://dx.doi.org/10.1590/S0100$\underline{204 X 2001000400007}$

Mahuku G, Montoya C, Henríquez MA, Jara C, et al. (2004). Inheritance and characterization of the angular leaf spot resistance gene in the common bean accession, G 10474 and identification of an AFLP marker linked to the resistance gene. Crop Sci. 44: 1817-1824. http://dx.doi.org/10.2135/cropsci2004.1817

Mendes FF, Ramalho MAP and Abreu AFB (2009). Índice de seleção para escolha de populações segregantes de feijoeirocomum. Pesquisa Agropecu. Bras. 44: 1312-1318. http://dx.doi.org/10.1590/S0100-204X2009001000015

Menezes Júnior JAN, Rezende Júnior LS, Rocha GS, Silva VMP, et al. (2013). Two cycles of recurrent selection in red bean breeding. Crop Breed. Appl. Biotechnol. 13: 41-48. http://dx.doi.org/10.1590/S1984-70332013000100005

Miklas PN, Kelly JD, Beebe SD and Blair MW (2006). Common bean breeding for resistance against biotic and abiotic stresses: from classical to MAS breeding. Euphytica 147: 105-131. http://dx.doi.org/10.1007/s10681-006-4600-5

Miranda Filho JB and Geraldi IO (1984). An adapted model for the analysis of partial diallel crosses. Braz. J. Genet. 7: $677-688$.

Moreto AL, Ramalho MAP, Nunes AR and Abreu AFB (2007). Estimação dos componentes da variância em feijoeiro utilizando o método genealógico. Cienc. Agrotec. 31: 1035-1042. http://dx.doi.org/10.1590/S1413$\underline{70542007000400014}$

Oliveira AMC, Batista RO, Carneiro PCS, Carneiro JES, et al. (2015). Potential of hypocotyl diameter in family selection aiming at plant architecture improvement of common bean. Genet. Mol. Res. 14: 11515-11523. http://dx.doi. org/10.4238/2015.September.28.3

Pereira HS, Melo LC, Faria LC, Wendland A, et al. (2013). BRS Esteio- common bean cultivar with black grain, high yield potential and moderate resistance to anthracnose. Crop Breed. Appl. Biotechnol. 13: 373-376. http://dx.doi. org $/ 10.1590 / \mathrm{S} 1984-70332013000400010$

Peternelli LA, Borem A and Carneiro JES (2009). Hibridação em feijão. In: Hibridação artificial de plantas (Borém A, ed.). Editora UFV, Viçosa, Brazil, 514-536.

Pires LPM, Ramalho MAP, Abreu AFB and Ferreira MC (2014). Recurrent mass selection for upright plant architecture in common bean. Sci. Agric. 71: 240-243. http://dx.doi.org/10.1590/S0103-90162014000300009

Ramalho MAP, Pirola LH and Abreu AFB (1998a). Alternativas na seleção de plantas de feijoeiro com porte ereto e grão tipo carioca. Pesquisa Agropecu. Bras. 33: 1989-1994.

Ramalho MAP, Abreu AFB and Santos PSJ (1998b). Interação genótipos x épocas de semeadura, anos e locais na avaliação de cultivares de feijão nas regiões Sul e Alto Paranaíba em Minas Gerais. Cienc. Agrotec. 2: 176-181.

Ramalho MAP, Abreu AFB and Santos JB (2001). Melhoramento de espécies autógamas. In: Recursos genéticos e melhoramento de plantas. (Nass LL, Valois ACC, Melo IS and Valadares-Inglis MC, eds.). Fundação MT, Rondonópolis, 201-230.

Ramalho MAP, Abreu AFB and Santos JB (2005). Genetic progress after four cycles of recurrent selection for yield and grain traits in common bean. Euphytica 144: 23-29. http://dx.doi.org/10.1007/s10681-005-5694-x

Ramalho MAP, Abreu AFB, Santos JB and Nunes JAR (2012). Aplicações da genética quantitativa no melhoramento de plantas autógamas. UFLA, Lavras, Brazil.

Sartorato A (2002). Identification of Phaeoisariopsis griseola pathotypes from five States in Brazil. Fitopatol. Bras. 27: 78-81. http://dx.doi.org/10.1590/S0100-41582002000100012

Sartorato A and Alzate-Marin AL (2004). Analysis of the pathogenic variability of Phaeoisariopsis griseola in Brazil. Annu. Rep. Bean Improv. Coop. 47: 235-237.

Silva FB, Ramalho MAP and Abreu AFB (2007). Seleção recorrente fenotípica para florescimento precoce de feijoeiro 'Carioca'. Pesquisa Agropecu. Bras. 42: 1437-1442. http://dx.doi.org/10.1590/S0100-204X2007001000010

Silva VMP, Carneiro PCS, Menezes Júnior JAN, Carneiro VQ, et al. (2013). Genetic potential of common bean parents for plant architecture improvement. Sci. Agric. 70: 167-175. http://dx.doi.org/10.1590/S0103-90162013000300005

Teixeira FF, Ramalho MAP and Abreu AFB (1999). Genetic control of plant architecture in the common bean (Phaseolus vulgaris L.). Genet. Mol. Biol. 22: 577-582. http://dx.doi.org/10.1590/S1415-47571999000400019

Torga PP, Melo PGS, Pereira HS, Faria LC, et al. (2013). Interaction of common beans cultivars of the black group with years, locations and sowing seasons. Euphytica 189: 239-248. http://dx.doi.org/10.1007/s10681-012-0793-y

Vale NM, Barili LD, Oliveira HM, Carneiro JES, et al. (2015). Escolha de genitores quanto à precocidade e produtividade de feijão tipo carioca. Pesquisa Agropecu. Bras. 50: 141-148. http://dx.doi.org/10.1590/S0100-204X2015000200006

Genetics and Molecular Research 15 (3): gmr.15038574 